\title{
EGFR T790M Mutation Positive Non-Small Cell Lung Carcinoma
}

National Cancer Institute

\section{Source}

National Cancer Institute. EGFR T790M Mutation Positive Non-Small Cell Lung

Carcinoma. NCI Thesaurus. Code C150124.

A finding indicating the presence of the epidermal growth factor receptor T790M amino acid substitution mutation in a tumor sample from a patient with non-small cell lung carcinoma. 